\title{
The extracellular portion of the insulin receptor $\beta$-subunit regulates the cellular trafficking of the insulin-insulin receptor complex. Studies on Chinese hamster ovary cells carrying the Cys $860 \rightarrow$ Ser insulin receptor mutation
}

\author{
L Benzi, P Cecchetti ${ }^{1}$, A M Ciccarone, S Novelli, A Paoli, A Bertacca, M Maffei, D Maggi ${ }^{2}$, \\ G Andraghetti ${ }^{2}$, S Del Prato and R Cordera ${ }^{2}$ \\ Section of Diabetes, Department of Endocrinology and Metabolism, School of Medicine, University of Pisa, Italy, ${ }^{1}$ Institute of Clinical Physiology, \\ National Research Council, Pisa, Italy and ${ }^{2}$ Department of Endocrinology and Metabolism, School of Medicine, University of Genova, Italy
}

(Correspondence should be addressed to Luca Benzi, Section of Diabetes, Department of Endocrinology and Metabolism, Ospedale Cisanello, Via Paradisa 2, 56124 Pisa, Italy; Email: metabpi@immrmed.unipi.it)

\begin{abstract}
Objective: Chinese hamster ovary (CHO) cells transfected with human engineered insulin receptor (IR) cDNA to mutate Cys 860 to Ser (CHO-IR ${ }^{\mathrm{C} 860 \mathrm{~S}}$ ) showed a defective insulin internalization without affecting insulin binding and IR autophosphorylation. Moreover, this mutation reduces insulin receptor substrate (IRS)-1 tyrosine phosphorylation and insulin-induced metabolic and mitogenic effects. Altogether, these observations support a role of the extracellular domain of IR $\beta$-subunit in insulin and receptor intracellular targeting as well as in insulin signaling.

Design and methods: This study assesses in more details the effect of $\mathrm{IR}^{\mathrm{C} 860 \mathrm{~S}}$ mutation on the trafficking of the insulin-IR complex. In particular, IR internalization, phosphorylation, dissociation and recycling, as well as insulin degradation and retroendocytosis have been investigated in $\mathrm{CHO}$ cells overexpressing either wild type $\left(\mathrm{CHO}-\mathrm{IR}^{\mathrm{WT}}\right)$ or mutated IRs.

Results: the C860S mutation significantly decreases IR internalization both insulin stimulated and constitutive. In spite of a similar dissociation of internalized insulin-IR complex, recycling of internalized IR was significantly faster (half life $\left(\mathrm{t}_{1 / 2}\right)$ : $21 \mathrm{~min}$ vs $40 \mathrm{~min}, P<0.001$ ) and more extensive $(P<0.01)$ for $\mathrm{IR}^{\mathrm{C} 860 \mathrm{~S}}$ than for $\mathrm{IR}^{\mathrm{WT}}$. On the other hand, insulin degradation and retroendocytosis were superimposable in both cell lines. As expected, insulin-induced phosphorylation was similar in both IRs, however dephosphorylation was much more rapid and was greater $(P<0.01)$ in CHO-IR ${ }^{\mathrm{WT}}$ as compared with CHO-IR ${ }^{\mathrm{C} 860 \mathrm{~S}}$ cells.

Conclusions: Transmembrane and intracellular domain of IR seem to be determinants for IR internalization. Now we report that Cys 860 in the IR $\beta$-subunit ectodomain may be of relevance in ensuring a proper internalization and intracellular trafficking of the insulin-IR complex.
\end{abstract}

European Journal of Endocrinology 148 365-371

\section{Introduction}

Upon insulin binding with the specific membrane receptor (IR) (1), the insulin-IR complex is internalized $(2,3)$. It has been suggested that this process contributes to modulation of insulin action by regulating IR number (4). Once internalized, the IR can undergo subcellular compartmentalization (5), but the vast majority is returned to plasma membrane via a recycling pathway (6). IR internalization and down-regulation require the coordinated action of several cellular mechanisms (7-9). The IR transmembrane region and flanking amino acids seem to play a key role (7). Moreover, internalization motifs have been identified in the juxtamembrane cytoplasmic domain (9). Finally,
IR tyrosine kinase activity is required for the endocytosis of the insulin-IR complex (10).

The extracellular domain of IR $\beta$-subunit regulates the $\beta$-subunit phosphorylation (11). Transfection of Chinese hamster ovary (CHO) cells with human engineered IR cDNA to mutate Cys 860 to Ser $\left(\mathrm{CHO}-\mathrm{IR}^{\mathrm{C} 860 \mathrm{~S}}\right)$ in the extracellular domain of IR $\beta$-subunit reduces insulin internalization (12), as well as insulin receptor substrate (IRS)-1 tyrosine phosphorylation, but not Shc phosphorylation (13). These actions are associated with a reduction in insulin-induced metabolic and mitogenic effects. These findings indicate a function of the extracellular domain of IR $\beta$-subunit in insulin signaling and IR intracellular compartmentalization. 
Here, we have determined in more detail the role of C860S in the intracellular targeting of the insulin-IR complex and in the regulation of insulin degradation and retroendocytosis.

\section{Materials and methods}

\section{Mutagenesis of cysteine 860 with serine in the extracellular portion of IR $\beta$-subunit}

Mutation of cysteine 860 with serine was performed as previously described (12). Briefly, a pCMV-HIR plasmid was used as template (12). PCR reactions were carried out to give two fragments of 918 and 1949 bp respectively, using the following primers: A, 5'-CTGGTCACCTTTTCGGATGAAC-3'; B, 5'-CCCTCTGCCTCTCTACG-3'; C, 5'-GCATCTCTCCGTCTCCC-3'; D, 5'-GCACTGGAGTGGCAACTTCCAA-3'. The intermediate products were hybridized together and used as a template for a further amplification using primers A and D. After digestion with Bsm1 and Afl2, the resulting DNA fragment was bound into pCMV-HIR plasmid, replacing the corresponding Bsm1-Alf2 wild type (WT) sequence. The entire DNA fragment produced by PCR was then sequenced by deoxy sequencing to confirm the absence of other mutations.

\section{Cell culture and transfection}

Chinese hamster ovary cells (CHOK1), grown in DMEM medium with $10 \%$ fetal calf serum, were stably transfected with $\mathrm{IR}^{\mathrm{C} 860 \mathrm{~S}}$ and screened for high level of expression by A14- ${ }^{125}$ I-insulin binding. A clonal cell line was obtained as previously described (12). The generation of the CHO cell line CHO-IR ${ }^{W T}$ has been described previously (12).

For the purpose of the study, cells were grown to subconfluence and serum-starved in F12 medium with $0.5 \%$ BSA for $16-24 \mathrm{~h}$ before each experiment.

\section{Insulin receptor internalization and insulin receptor recycling}

In order to reach maximal receptor internalization, cells expressing WT or mutated IR were incubated in Hepes buffer $(50 \mathrm{mmol} / \mathrm{l}$ Hepes; $120 \mathrm{mmol} / \mathrm{l} \mathrm{NaCl} ; 1 \mathrm{mmol} / \mathrm{l}$ $\mathrm{MgSO}_{4} ; 5 \mathrm{mmol} / \mathrm{l} \mathrm{KCl} ; 1 \mathrm{mmol} / \mathrm{l} \mathrm{CaCl}_{2}$ and $1 \% \mathrm{BSA}$; $\mathrm{pH}$ 7.8 ) at $37^{\circ} \mathrm{C}$ for different time periods in the presence of $100 \mathrm{nmol} / \mathrm{l}$ unlabeled insulin. At the end of each incubation period, insulin bound to surface receptors was removed by acid ( $\mathrm{pH} 4.5)$ wash (14). Insulin binding was measured before and at different times after cell exposure to unlabeled insulin. IR internalization studies were also repeated in the absence of insulin after 60-min incubation with $50 \mu \mathrm{mol} / \mathrm{l}$ monensin (Sigma, St Louis, MO, USA) at $37^{\circ} \mathrm{C}$. Monensin traps internalized IR in the intracellular compartment, allowing measurement of constitutive IR internalization (15). Insulin receptor recycling was evaluated after maximal receptor internalization by reincubating cells at $37^{\circ} \mathrm{C}$ in an insulin-free medium to allow internalized receptor to return to the cell surface. Insulin binding was measured when maximal internalization was reached (time 0) and at 30, 60 and $90 \mathrm{~min}$ during rewarming. For insulin receptor binding measurement, cells were incubated with HPLC purified A14- ${ }^{125} \mathrm{I}$-insulin $(34 \mathrm{pmol} / \mathrm{l})$ (16) in Hepes buffer $(\mathrm{pH} 7.8)$ at $16^{\circ} \mathrm{C}$ for $180 \mathrm{~min}$. Then, cells were extensively washed with cold PBS and solubilized with $0.4 \mathrm{~mol} / \mathrm{l} \mathrm{NaOH}$, before counting on a $\gamma$-counter (Packard Instrument, Dowers Grove, IL, USA).

\section{Dissociation of the insulin receptor complex}

After 60-min incubation with A14- ${ }^{125}$ I-insulin at $37^{\circ} \mathrm{C}$, cells were either washed 3 times with both cold PBS and acid solution (14) or washed and reincubated for different time periods at $37^{\circ} \mathrm{C}$ in an insulin-free medium. At the end of each time period, cells were scraped and solubilized for $30 \mathrm{~min}$ in cold $0.5 \%$ Triton X-100, in order not to disrupt the insulin-receptor complexes $(17,18)$, in $25 \mathrm{mmol} / \mathrm{l}$ Hepes buffer $(\mathrm{pH}$ $7.5)$ containing $0.1 \mathrm{mg} / \mathrm{ml}$ aprotinin. One aliquot of the solubilized cells was then counted for measurement of total cell associated radioactivity, while a second aliquot was combined with $350 \mu \mathrm{l} 1 \% \gamma$-globulin in PBS and $700 \mu \mathrm{l} \mathrm{25 \%}$ polyethylene glycol (PEG). The aliquot was then centrifuged in a microfuge at $4{ }^{\circ} \mathrm{C}$ for $5 \mathrm{~min}$. The supernatant was removed and the radioactivity in the pellet counted and corrected for unspecific insulin precipitation $(<2 \%)$.

\section{Assessment of IR dephosphorylation}

Cells were grown to subconfluence and serum-starved in DMEM (Sigma Chemical Co., St. Louis, MO, USA) for $12 \mathrm{~h}$ before the experiments. Phosphorylation of the $\beta$-subunit of IR was obtained by cell incubation with $10 \mathrm{nmol} / \mathrm{l}$ insulin for $10 \mathrm{~min}$ at $37^{\circ} \mathrm{C}$. For dephosphorylation assessment, cells were acid washed to remove insulin bound to surface receptors, and resuspended in Hepes buffer at $37^{\circ} \mathrm{C}$. To evaluate phosphorylation, cells were washed with cold PBS and then $500 \mu \mathrm{l}$ lysis solution $(50 \mu \mathrm{l}$ of $150 \mathrm{mmol} / \mathrm{l}$ Tris, $\mathrm{pH} 6.8,6.9 \%$ SDS, $30 \%$ glycerol, and $100 \mathrm{mmol} / \mathrm{l}$ dithiothreitol, heated at $100^{\circ} \mathrm{C}$ for $2 \mathrm{~min}$ ) were added. Lysed cells were centrifuged at $15000 \boldsymbol{g}$ for $40 \mathrm{~min}$ and the supernatant immunoprecipitated with anti-IR antibody (Upstate Biotechnology, Lake Placid, NY, USA) for $14 \mathrm{~h}$ at $4^{\circ} \mathrm{C}$. Protein A-Sepharose was then added and the incubation continued for a further $90 \mathrm{~min}$. Sepharose-bound immunocomplexes were washed with the lysis buffer and boiled for $5 \mathrm{~min}$ in Laemmli sample buffer. Samples were then resuspended in $7.5 \%$ SDS-PAGE for electrophoresis analysis. The separated proteins were transferred to nitrocellulose mem- 
branes using appropriate buffer $(20 \mathrm{mmol} / \mathrm{l}$ Tris, $150 \mathrm{mmol} / \mathrm{l}$ glycine, $20 \%$ methanol, $0.02 \% \mathrm{SDS}$ ) for $1 \mathrm{~h}$ at $150 \mathrm{~mA}$. Nitrocellulose filters were blocked in PBS, $0.1 \%$ Tween 20 and 5\% BSA for $1 \mathrm{~h}$ at room temperature. Filters were then incubated with anti-IR antibody or with anti-phosphotyrosine antibody (Transduction Laboratories, Lexington, KY, USA) for $2 \mathrm{~h}$ at room temperature (13). After final washing in PBS $0.1 \%$ Tween 20, bound antibodies were detected by enhanced chemiluminescence reagents according to the manufacturer's instructions (ECL; Amersham Pharmacia Biotech, Little Chalfont, Bucks, UK). The bands were quantified by a GS-690 Bio-Rad Densitometer with Multi Analyst-PS Software for image analysis (Dc Protein Assay; Bio-Rad Laboratories, Hercules, CA, USA). All results were normalized for $\mathrm{mg} /$ protein.

\section{Insulin degradation}

CHO cells expressing wild-type or $\mathrm{IR}^{\mathrm{C} 860 \mathrm{~S}}$ were incubated at $37^{\circ} \mathrm{C}$ in Hepes buffer with $6.7 \mathrm{nmol} / \mathrm{l}$ A14- ${ }^{125}$ I-insulin in the presence or absence of $16.6 \mu \mathrm{mol} / \mathrm{l}$ unlabeled insulin for $60 \mathrm{~min}$. At the end of the incubation period, the medium was removed, the cells were washed with cold PBS and incubated in Hepes buffer $\left(\mathrm{pH} \mathrm{3.5)}\right.$ for $10 \mathrm{~min}$ at $4^{\circ} \mathrm{C}$. Cells were then scraped and suspended in ice-cold $0.25 \mathrm{~mol} / \mathrm{l}$ sucrose, $5 \mathrm{mmol} / \mathrm{l}$ Tris, $8 \mu \mathrm{g} / \mathrm{ml}$ aprotinin, $2 \mathrm{mmol} / \mathrm{l}$ phenylmethylsulfonyl fluoride, $2 \mathrm{mmol} / \mathrm{l}$ orthovanadate ( $\mathrm{pH}$ 7.4) and homogenized on a Dounce homogenizer (Kontes Glass Co., Vineland, NJ, USA). Nuclei and mitochondria were removed by centrifugation at $5000 \boldsymbol{g}$ for $3 \mathrm{~min}$ at $4{ }^{\circ} \mathrm{C}$ and vesicles were collected from the supernatant by centrifugation at $40000 \mathrm{~g}$ for $10 \mathrm{~min}$ (Kontron Instruments T-2070, Zurich, Switzerland). Endosomes were separated from lysosomes by centrifugation at $40000 \boldsymbol{g}$ for $1 \mathrm{~h}$ at $4{ }^{\circ} \mathrm{C}$ through self-forming Percoll gradient (starting density $1.07 \mathrm{~g} / \mathrm{ml}$ ). Fractions containing the endosomal vesicles were then pooled and the Percoll was removed by centrifugation at $100000 \mathrm{~g}$ for $30 \mathrm{~min}$ at $4^{\circ} \mathrm{C}$. To determine endosomal radioactivity, the endosome fraction was solubilized with $0.1 \%$ Triton $\mathrm{X}-100$ and $3 \mathrm{~mol} / \mathrm{l}$ acetic acid for $1 \mathrm{~h}$ at $4^{\circ} \mathrm{C}$ and was centrifuged in a microfuge for $30 \mathrm{~min}$ at $20000 \mathrm{~g}$ at $4^{\circ} \mathrm{C}$. Labeled intact insulin in the endosomal fraction was finally determined by HPLC analysis using a Waters C18 $\mu$ Bondapack (average particle size $10 \mu \mathrm{m})$ column $(300 \times 3.9 \mathrm{~mm}$ I.D. $)$ (Waters Associated, Milford, MA, USA) with $0.001 \mathrm{~mol} / \mathrm{l}$ sodium phosphate buffer-isopropanolacetonitrile $(68: 11: 21 \mathrm{v} / \mathrm{v} / \mathrm{v})$ containing $0.15 \mathrm{~mol} / \mathrm{l}$ ammonium acetate and adjusted to $\mathrm{pH} 3.0$ by hydrochloric acid as the mobile phase (19).

\section{Insulin retroendocytosis}

In order to measure the release of intact A14- ${ }^{125}$ I-insulin from the intracellular compartment to medium,
CHO cells overexpressing $\mathrm{IR}^{\mathrm{WT}}$ or $\mathrm{IR}^{\mathrm{C} 860 \mathrm{~S}}$, after incubation with $6.7 \mathrm{nmol} / \mathrm{l}$ labeled insulin for $30 \mathrm{~min}$ at $37^{\circ} \mathrm{C}$ to obtain maximal IR internalization, were acid washed to remove insulin bound to surface receptors and were then resuspended in insulin-free Hepes buffer at $37^{\circ} \mathrm{C}$. Aliquots of the incubation medium were then collected at given times for HPLC determination of intact insulin (19).

\section{Statistical analysis}

All the results are expressed as means \pm s.D. of three experiments performed in triplicate. Statistical significance was assessed using a two-way analysis of variance (ANOVA) performed by StatView II (SAS Institute Inc., Cary, NC, USA).

\section{Results}

\section{IR internalization}

As previously reported, C860S substitution does not affect insulin receptor binding affinity either in vivo or in vitro (12) suggesting that Cys860 is not essential for insulin binding. As shown in Fig. 1, after $30 \mathrm{~min}$ incubation with labeled insulin at $37^{\circ} \mathrm{C}$, IR internalization reached a plateau in both $\mathrm{CHO}-\mathrm{IR}^{\mathrm{WT}}$ and CHO-IR ${ }^{\text {C60S }}$ cells. However, in these latter cells the residual insulin binding was significantly higher compared with CHO-IR ${ }^{\mathrm{WT}}$ cells $(88 \pm 3 \%$ vs $67 \pm 8 \%$; $P<0.01)$. The defect in receptor internalization in CHO-IR ${ }^{\text {C660 }}$ cells was not dependent on insulin availability in the medium, since similar results occurred also after incubation with monensin. These results

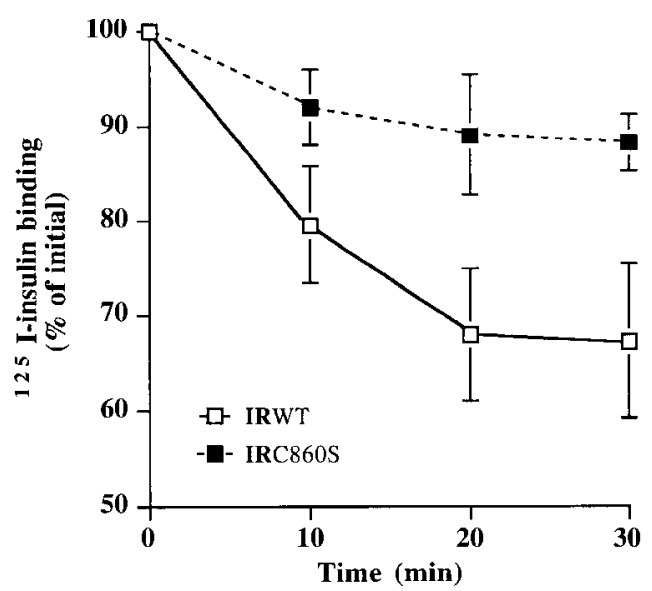

Figure 1 Time course of insulin-stimulated IR internalization in $\mathrm{CHO}-\mathrm{IR}^{\mathrm{WT}}$ and $\mathrm{CHO}-\mathrm{IR}^{\mathrm{C} 860 \mathrm{~S}}$ cells. Cells were incubated at $37^{\circ} \mathrm{C}$ for different times in the presence of $100 \mathrm{nmol} / \mathrm{l}$ insulin. At the indicated times, cells were acid washed and insulin binding was performed. Results are expressed as percentage of initial A14- ${ }^{125}$ I-insulin binding. The residual insulin binding in $\mathrm{CHO}$ $\mathrm{IR}^{\mathrm{C} 860 \mathrm{~S}}$ cells was significantly higher $(P<0.01)$ as compared with that of $\mathrm{CHO}-\mathrm{IR}^{\mathrm{WT}}$ cells. Results are reported as means \pm S.D. 
show that C860S substitution reduces both insulin induced and constitutive IR internalization.

\section{Insulin-IR complex dissociation, IR dephosphorylation and recycling}

After insulin-IR complex internalization, IR dissociates from insulin in the endosome (14). This step is critical for further sorting and trafficking of insulin and IR (2). After maximal IR internalization, acid washing was associated with similar values of intracellular PEGprecipitable radioactivity in both solubilized cell lines $\left(38 \pm 8 \%\right.$ and $44 \pm 7 \%$ in $\mathrm{CHO}-\mathrm{IR}^{\mathrm{WT}}$ and $\mathrm{CHO}-\mathrm{IR}^{\mathrm{C} 860 \mathrm{~S}}$ cells respectively). Percentage decremental change from baseline of PEG-precipitable radioactivity is illustrated in Fig. 2, showing a comparable time course and half life $\left(\mathrm{t}_{1 / 2}\right)$ of the dissociation process in the two cell lines.

We then measured the rate of IR dephosphorylation in the intracellular compartment. Upon insulin incubation, phosphorylation of the IR $\beta$-subunit was superimposable in $\mathrm{CHO}-\mathrm{IR}^{\mathrm{WT}}$ and $\mathrm{CHO}-\mathrm{IR}^{\mathrm{C} 860 \mathrm{~S}}$ cells (Fig. 3A, time 0). Cell reincubation in an insulin-free medium was associated with IR $\beta$-subunit dephosphorylation in both cell lines. Nonetheless, the rate of the dephosphorylation process was much more rapid and was greater in $\mathrm{CHO}-\mathrm{IR}^{\mathrm{WT}}$ than in $\mathrm{CHO}-\mathrm{IR}^{\mathrm{C} 860 \mathrm{~S}}$ cells $(P<0.01$; Fig. 3B).

After maximal internalization, IR was allowed to recycle to plasma membrane by reincubating cells at

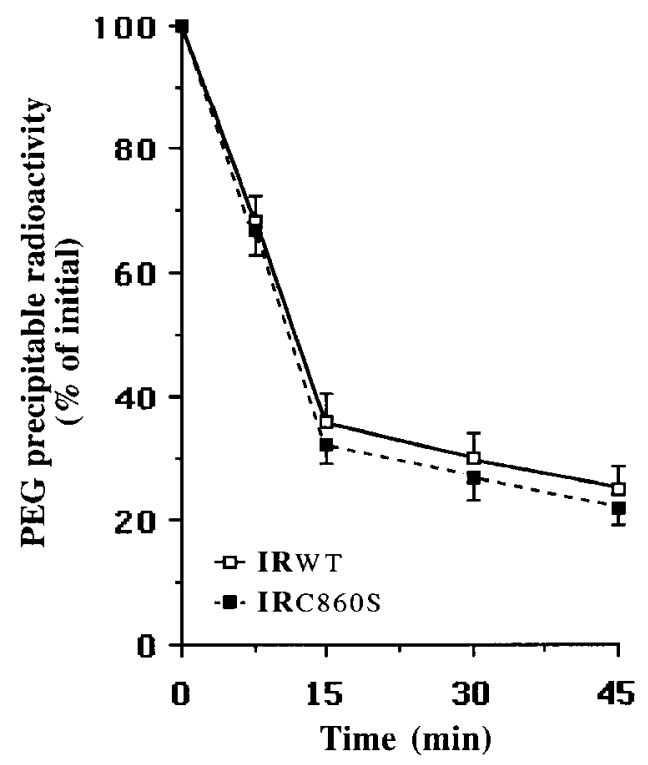

Figure 2 Time course of intracellular PEG precipitable radioactivity in $\mathrm{CHO}-\mathrm{IR}^{\mathrm{WT}}$ and $\mathrm{CHO}-\mathrm{IR}^{\mathrm{C} 860 \mathrm{~S}}$ cells. Cells were incubated in the presence of $\mathrm{A} 14^{-125} \mathrm{I}$-insulin for $30 \mathrm{~min}$ at $37^{\circ} \mathrm{C}$, acid washed, re-incubated in insulin-free medium at $37^{\circ} \mathrm{C}$ and solubilized at the indicated times. At each time studied, intracellular radioactivity was analyzed for the ability to precipitate in $12.5 \%$ PEG. Results are reported as means \pm S.D. $37^{\circ} \mathrm{C}$ in an insulin-free buffer and the recovery of insulin binding was measured at different times. The recycling of IR from intracellular compartment to plasma membrane was much faster for mutated $\left(\mathrm{t}_{1 / 2}\right.$ $21 \mathrm{~min})$ than for $\mathrm{WT}\left(\mathrm{t}_{1 / 2} 40 \mathrm{~min}, \mathrm{P}<0,001\right.$, Fig. 4) receptors. Moreover, the recovery of baseline insulin binding after $90 \mathrm{~min}$ rewarming was slightly but significantly lower in $\mathrm{CHO}-\mathrm{IR}^{\mathrm{WT}}$ compared with CHO-IR ${ }^{\text {C860S }}$ cells $(90 \pm 6$ vs $98 \pm 1 \%, P<0.01)$.

\section{Insulin degradation and retroendocytosis}

Following internalization, insulin is then either degraded in the intracellular compartment or released undegraded into the extracellular medium (retroendocytosis) (2). To study intracellular insulin degradation, cells were incubated with A14- ${ }^{125} \mathrm{I}$-insulin at $37^{\circ} \mathrm{C}$ for
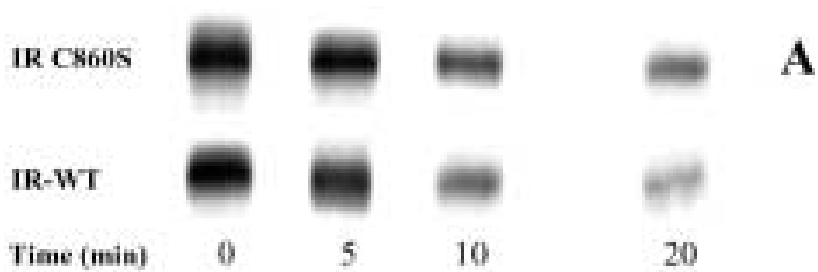

6

10

20

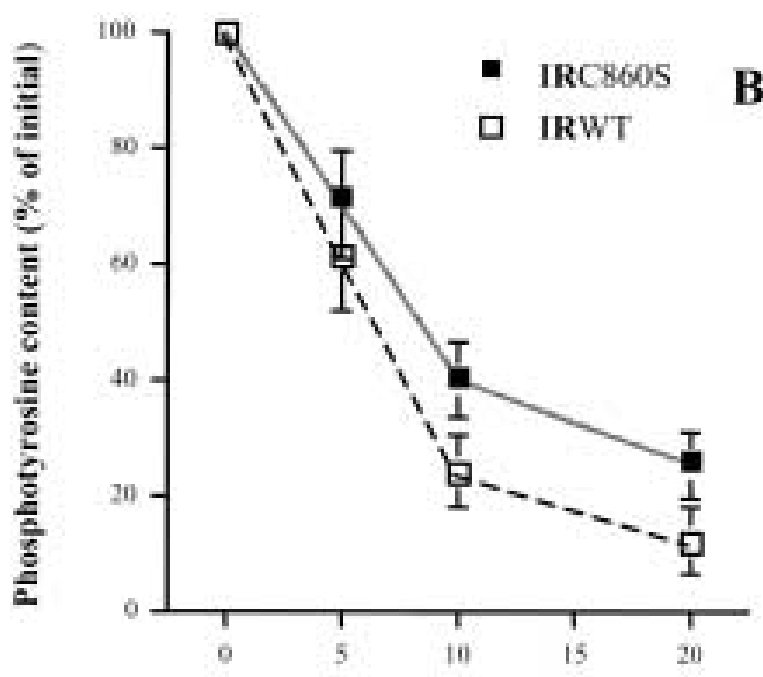

Time (min)

Figure 3 (A) Time course of loss of phosphotyrosine content of insulin receptor $\beta$-subunit. Maximal receptor phosphorylation was obtained by incubating cells with $10 \mathrm{nmol} / \mathrm{l}$ insulin at $37^{\circ} \mathrm{C}$ for $10 \mathrm{~min}$. After acid washing, cells were reincubated in an insulinfree medium. At the indicated times, cells were solubilized, receptors immunoprecipitated and subjected to SDS-PAGE. Phosphotyrosine receptor content was assessed by immunoblotting with anti-phosphotyrosine antibodies. (B) Insulin receptor phosphorylation was quantified by scanning densitometry after normalization for $\mathrm{mg} /$ protein and expressed as a percentage of maximal receptor phosphorylation (100\%). The loss of phosphotyrosine content of IR ${ }^{\mathrm{WT}}$ was significantly different $(P<0.01)$ compared with $\mathrm{IR}^{\mathrm{C} 860 \mathrm{~S}}$. Results are reported as means \pm S.D. 


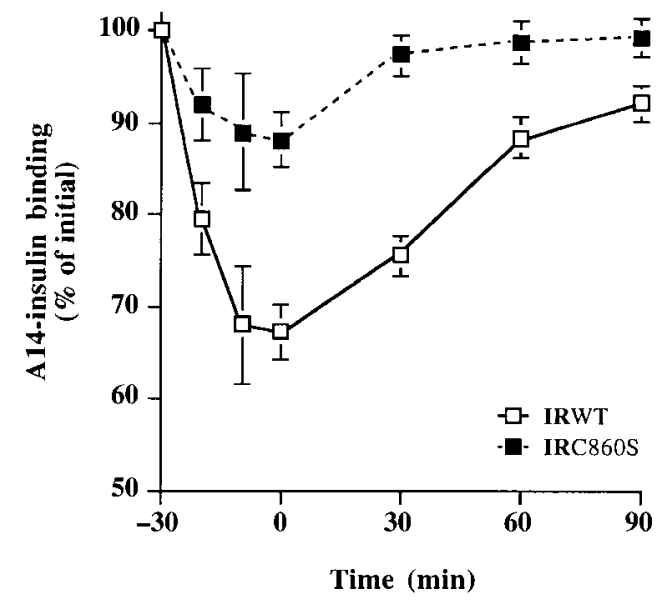

Figure 4 Recovery of cell surface $\mathrm{A} 14^{-125}$ I-insulin binding in $\mathrm{CHO}-\mathrm{IR}^{\mathrm{WT}}$ and $\mathrm{CHO}-\mathrm{IR}^{\mathrm{C} 860 \mathrm{~S}}$ cells. IRs were allowed to internalize, as described in Materials and methods. Then, CHO-IR ${ }^{W T}$ and $\mathrm{CHO}-\mathrm{IR}^{\mathrm{C} 860 \mathrm{~S}}$ cells were acid washed and incubated in insulin-free medium at $37^{\circ} \mathrm{C}$ for the indicated times to allow recovery of cell surface insulin binding. The recovery of insulin binding in $\mathrm{CHO}-\mathrm{IR}^{\mathrm{C} 860 \mathrm{~S}}$ cells was much faster and more complete $(P<0.01)$ compared with that of $\mathrm{CHO}-\mathrm{IR}^{\mathrm{WT}}$ cells. Results are reported as means \pm S.D.

$30 \mathrm{~min}$ to obtain maximal insulin internalization. Insulin degradation, determined in endosomal vesicles by assessment of intact insulin by HLPC, was not different in CHO-IR ${ }^{W T}(88 \pm 3 \%)$ and $\mathrm{CHO}-\mathrm{IR}^{\mathrm{C} 60 \mathrm{~S}}$ $(88 \pm 4 \%)$ cells.

To evaluate insulin retroendocytosis, cells were allowed to internalize insulin, were then acid washed and resuspended for different times at $37^{\circ} \mathrm{C}$ in an insulin-free medium and intact insulin released into the medium was assessed by HPLC. As shown in Fig. 5 the ratio of intact insulin to total radioactivity (intact insulin plus degradation products) extruded from cells into the medium, was similar between $\mathrm{CHO}-\mathrm{IR}^{\mathrm{WT}}$ and CHO-IR ${ }^{\text {C860S }}$ cells. Moreover, the time course of insulin retroendocytosis was similar in the two cell types.

\section{Discussion}

Insulin receptor internalization and recycling is a physiological phenomenon, very likely associated with insulin signaling modulation (20). Defects of the internalization and recycling of the insulin-IR complex have been described in conditions associated with insulin resistance, such as Type 2 diabetes (21) and obesity (22). Moreover, insulin sensitizer agents, like metformin, improve insulin sensitivity and restore insulin-IR complex internalization and trafficking (22). Therefore, unraveling the factors controlling insulin-IR complex trafficking may provide useful insight into the multiple pathogenetic mechanisms involved in insulin resistance. Among the various factors regulating this fine process, the intracellular and transmembrane portion of IR $\beta$-subunit have been shown to play a role $(23-26)$. On the other hand, it has previously been shown that the extracellular domain of IR $\beta$-subunit regulates IR targeting (12). In particular, C860S substitution impairs the lateral translocation of the insulin-IR complex on the cell surface, prevents IR down-regulation and causes, in CHO cells, a condition of insulin resistance by impairing IRS-1 tyrosine phosphorylation without affecting IR autophosphorylation $(12,13)$.

Here we provide clear cut evidence that the C860S mutation in the IR $\beta$-subunit causes an impairment of insulin-induced IR internalization in spite of normal activation of IR autophosphorylation. Previously published data (12) have shown that C860S mutation does not affect insulin receptor binding affinity either in vivo or in vitro. These data rule out the possibility that the differences observed are due to altered kinetics of insulin binding and sensitivity in $\mathrm{CHO}^{\mathrm{IR}}{ }^{\mathrm{C} 860 \mathrm{~S}}$ compared with CHO-IR ${ }^{\mathrm{WT}}$ cells. Moreover constitutive internalization of the IR determined in the presence of monensin which prevents endosome acidification, was found to be reduced in the CHO-IR ${ }^{\mathrm{C} 860 \mathrm{~S}}$ cells (27-29). C860S substitution does not affect the rate of insulin-IR complex dissociation, insulin retroendocytosis and degradation which are similar in both cell types. This result is at variance with those of Yamada et al. (30). In their hands, insulin degradation in wild type cells was $24 \%$, with a slight reduction in $\mathrm{CHO}$ cells expressing human receptors mutated in their extracellular domain. A major difference, however, between their study and the present one resides in the methodology used for determination of insulin degradation.

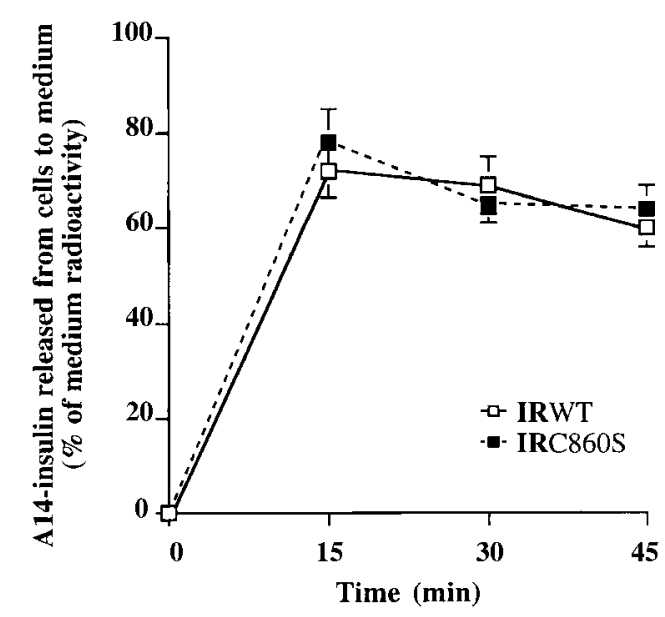

Figure $\mathbf{5}$ Time course of the appearance in the medium of intact A14- ${ }^{125}$ I-insulin. Cells were incubated with A14- ${ }^{125}$ I-insulin for $30 \mathrm{~min}$ at $37^{\circ} \mathrm{C}$ to allow insulin internalization. After acid washing cells were reincubated at $37^{\circ} \mathrm{C}$ in an insulin-free medium and intact $A 14-{ }^{125}$ I-insulin released from cells to medium was characterized by HPLC. Results are reported as the ratio of intact A14- ${ }^{125}$ I-insulin/total medium radioactivity (insulin plus degradation products, $100 \%$ ). Results are reported as means \pm S.D. 
While we used an HPLC technique for separation of degraded insulin, in Yamada's study the trichloroacetic acid precipitation was employed, a technique which is known to overestimate insulin degradation (30). Although insulin-IR complex dissociation and insulin degradation do not seem to be affected by the C860S mutation, the insulin receptor recycling appears to be faster and more extensive for mutated receptor. Since dissociation and degradation occur at the endosomal level upon acidification, the main effect of the mutation seems to be exerted at post-endosomal steps. Another step that does not seem to be affected in CHO-IR ${ }^{\mathrm{C} 860 \mathrm{~S}}$ cells is insulin retroendocytosis, suggesting that recycling of the IR and retroendocytosis of insulin occur via independent mechanisms. This observation is in full agreement with both biochemical (26) and morphological (31) studies showing that the receptor and its ligand physically segregate and move in separate vesicular structures. Moreover, since a backward transport of intact insulin-IR complex is unlikely, our estimate of insulin receptor recycling cannot be underestimated.

In spite of faster and more complete recycling of the mutated IR, its rate of dephosphorylation was lower when compared with the wild type IR. The nature of this difference is not readily apparent. Because the internalization of the mutated receptor is impaired, one could argue that the reduction of dephosphorylation is due to its predominant localization on the plasma membrane during insulin stimulation. The low fraction of mutated insulin receptor presented to specific intracellular phosphatases could then account for low dephosphorylation. However, this view is not supported by current knowledge that the dephosphorylation of activated IR occurs both on the plasma membrane and within the intracellular compartment. In intact cells, surface localized insulin receptors are dephosphorylated by a specific transmembrane protein tyrosine phosphatase (PTP $\alpha)$ (32). An impairment of $\mathrm{IR}^{\mathrm{C} 860 \mathrm{~S}}$ dephosphorylation by $\mathrm{PTP} \alpha$ seems unlikely as both IR and PTP $\alpha$ segregate in the same microenvironment and there are no data to support a decreased sensitivity of the mutated receptor to PTP $\alpha$. In fact, we have already shown that C860S mutation does not modify insulin binding, $\beta$-subunit IR autophosphorylation, $\beta$-subunit and IRS-1 association (12). On the other hand, after the endosomal dissociation of insulin, IR is rapidly dephosphorylated $(33,34)$. The intracellular activation of a protein tyrosine phosphatase (PTP1B) (35) has a major role in the negative regulation of insulin signaling. Thus, the abnormal intracellular routing of IR ${ }^{\mathrm{C} 860 \mathrm{~S}}$ may affect its potential association with PTP-1B (or other intracellular phosphatases) in various sub-cellular compartments. If we accept this hypothesis, we might conclude that C860S mutation accounts for an intracellular recycling of the insulin receptor that, in part, occurs via a non-dephosphorylating pathway.
In conclusion, Cys 860 in the IR $\beta$-subunit ectodomain regulates the early steps of IR intracellular targeting. C860 substitution redirects IR intracellular compartmentalization reducing the interaction with tyrosine phosphatases and increasing the recycling of mutated receptor, independently from insulin.

\section{Acknowledgements}

This work was supported by grants from the Ministero della Pubblica Istruzione (Ricerca Scientifica 1997) and the Italian Society of Diabetology (1997). R C, G A and D M acknowledge A.I.R.C. for financial support.

\section{References}

1 Virkamaki A, Ueki K \& Kahn CR. Protein-protein interaction in insulin signaling and molecular mechanisms of insulin resistance. Journal of Clinical Investigation 1999103 931-943.

2 Duckworth WC. Insulin degradation: mechanisms, products and significance. Endocrine Reviews 19889 319-345.

3 Backer JM, Shoelson SA, Haring E \& Write MF. Insulin receptors internalize by a rapid, saturable pathway requiring receptor autophosphorylation and an intact juxtamembrane region. Journal of Cell Biology 1991115 1535-1545.

4 Gavin JR, Roth J, Neville DM, DeMeyts P Jr \& Buell DN. Insulindependent regulation of insulin receptor concentrations: a direct demonstration in cell culture. PNAS 1974 71 84-88.

5 Bevan AP, Drake PG, Bergeron JJM \& Posner BI. Intracellular signal transduction: the role of endosomes. Trends in Endocrinology and Metabolism 19967 13-21.

6 Knutson VP. Cellular trafficking and processing of the insulin receptor. FASEB Journal 19915 2130-2138.

7 Yamada K, Carpentier JL, Cheatham B, Gouncalves E, Shoelson SE \& Kahn R. Role of the transmembrane domain and flanking amino acids in internalization and down-regulation of the insulin receptor. Journal of Biological Chemistry 1995270 3115-3122.

8 Gorden O, Carpentier JL, Freyebet P \& Orci L. Internalization of polypeptide hormones: mechanism, intracellular localization and significance. Diabetologia 198018 263-274.

9 Smith RM \& Jarret L. Receptor-mediated endocytosis and intracellular processing of insulin: ultrastructural and biochemical evidence for cell-specific heterogeneity and distinction from nonhormonal ligands. Laboratory Investigation $1988 \mathbf{5 8}$ 613-629.

10 Wilden PA, Kaha CR, Siddle K \& While MF. Insulin receptor kinase domain autophosphorylation regulates receptor enzymatic function. Journal of Biological Chemistry 1992267 16660-16668.

11 Gherzi R, Sesti G, Andraghetti G, De Pirro R, Lauro R, Adezati L et al. An extracellular domain of the insulin receptor beta-subunit with regulatory function on protein-tyrosine kinase. Journal of Biological Chemistry 198925 8627-8635.

12 Maggi D, Andraghetti G \& Cordera R. A Ser for Cys mutation in the extracellular portion of insulin receptor $\beta$-subunit impairs the insulin-insulin receptor complex internalization in $\mathrm{CHO}$ cells. Biochemical and Biophysical Research Communications 1995 $210931-937$.

13 Maggi D, Andraghetti G, Carpentier JL \& Cordera R. Cys860 in the extracellular domain of insulin receptor $\beta$-subunit is critical for internalization and signal transduction. Endocrinology 1998 139 496-504.

14 Borden LA, Einstein R, Gabel CA \& Maxfield FR. Acidificationdependent dissociation of endocytosed insulin precedes that of endocytosed proteins bearing the mannose 6-phosphate recognition marker. Journal of Biological Chemistry $1990 \mathbf{2 6 5}$ $8497-8504$. 
15 Soubigou P, Ali M \& Plas C. Uncoupling between the insulinreceptor cycles and the cellular degradation of the hormone in cultured fetal hepatocytes. Biochemical Journal $1987 \mathbf{2 4 6}$ 567-573.

16 Benzi L, Pezzino V, Marchetti P, Gullo D, Cecchetti P, Masoni A et al. A14- ${ }^{125}$ I monoiodoinsulin purified by different high-performance liquid chromatographic procedures and by polyacrylamide gel electrophoresis: preparation, immunochemical properties and receptor binding affinity. Journal of Chromatography $1986 \mathbf{3 7 8}$ 337-347.

17 Cuatrecasas P. Isolation of the insulin receptor of liver and fat-cell membranes. PNAS $198869318-322$.

18 Levy JR \& Olefsky JM. Intracellular insulin-receptor dissociation and segregation in a rat fibroblast cell line transfected with a human insulin receptor gene. Journal of Biological Chemistry $19882636101-6108$.

19 Benzi L, Cecchetti P, Ciccarone AM, Pilo A, Di Cianni G \& Navalesi R. Insulin degradation in vitro and in vivo: a comparative study in men. Diabetes $199443297-304$.

20 Backer JM, Kahn CR \& White MF. Tyrosine phosphorylation of the insulin receptor during insulin-stimulated internalization in rat hepatoma cells. Journal of Biological Chemistry $1989 \mathbf{2 6 4}$ 1694-1701.

21 Trischitta V, Brunetti A, Chiavetta A, Benzi L, Papa V \& Vigneri R. Defects in insulin-receptor internalization and processing in monocytes of obese subjects and obese NIDDM patients. Diabetes $1989381579-1584$.

22 Benzi L, Trischitta V, Ciccarone AM, Cecchetti P, Brunetti A, Squatrito $S$ et al. Improvement with metformin in insulin internalization and processing in monocytes from NIDDM patients. Diabetes $199039844-849$.

23 Backer JM, Kan CR, Cahill DA, Ullrich A \& White MF. Receptormediated internalization of insulin requires a 12-amino acid sequence in the juxtamembrane region of the insulin receptor $\beta$-subunit. Journal of Biological Chemistry $1990 \mathbf{2 6 5}$ 16450-16454.

24 Backer JM, Shoelson SE, Weiss MA, Hua QX, Cheatham RB, Haring $\mathrm{E}$ et al. The insulin receptor juxtamembrane region contains two independent tyrosine/ $\beta$-turn internalization signals. Journal of Cell Biology $1992 \mathbf{1 1 8} 831-839$.

25 Thies RS, Webster N \& McClain DA. A domain of the insulin receptor required for endocytosis in rat fibroblasts. Journal of Biological Chemistry 1990265 10132-10137.
26 Geuze HJ, Slot JW, Straus GJAM, Lodish HF \& Schwarts AL. Intracellular site of asialoglycoprotein receptor-ligand uncoupling: double-labeled immunoelectron microscopy during receptor-mediated endocytosis. Cell 198332 277-287.

27 Tartakoff AM. Perturbation of vesicular traffic with the carboxylic ionophore monensin. Cell 198332 1026-1028.

28 Backer JM, Kahn CR \& White MF. The dissociation and degradation of internalized insulin occur in the endosomes of rat hepatoma cells. Journal of Biological Chemistry 1990265 14828-14835.

29 Carpentier JL, Dayer J, Lang U, Silverman R, Orci L \& Gorden P. Down-regulation and recycling of insulin receptors. Effect of monensin on IM-9 lymphocytes and U-937 monocyte-like cells. Journal of Biological Chemistry 1984259 14190-14195.

30 Yamada K, Carpenter JL, Cheatham B, Gouncalves E, Shoelson SE \& Kahn R. Role of the transmembrane domain and flanking amino acids in internalization and down-regulation of the insulin receptor. Journal of Biological Chemistry 1995 270 3115-3122.

31 Baenziger JU \& Fiete D. Separation of populations of endocytotic vesicles involved in receptor-ligand sorting in rat hepatocytes. Journal of Biological Chemistry 1986261 7445-7454.

32 Elchebly M, Payette P, Michaliszyn E, Cromlish W, Collins S, Lee Loy A et al. Increased insulin sensitivity and obesity resistance in mice lacking the protein tyrosine phosphatase-1B gene. Science $19992831544-1548$.

33 Mooney RA \& Bordwell KL. Differential dephosphorylation of the insulin receptor and its $160 \mathrm{kDa}$ substrate (pp160) in rat adipocytes. Journal of Biological Chemistry $1992 \quad \mathbf{2 6 7}$ 14054-14060.

34 Faure R, Baquiran G, Bergeron JJM \& Posner BI. The dephosphorylation of insulin and epidermal growth factor receptors. Role of endosome-associated phosphotyrosine phosphatase(s). Journal of Biological Chemistry 1992267 11215-11222.

35 Lammers R, Moller NPH \& Ullrich A. The transmembrane protein tyrosine phosphatase $\alpha$ dephosphorylates the insulin receptor in intact cells. FEBS Letters $1997 \mathbf{4 0 4} 37-40$.

Received 17 July 2002

Accepted 15 November 2002 